\title{
SOCIAL POLICY DIMENSIONS OF ECONOMIC INTEGRATION: ENVIRONMENTAL AND LABOUR STANDARDS
}

Kym Anderson

NBER Working Paper 5702

\author{
NATIONAL BUREAU OF ECONOMIC RESEARCH \\ 1050 Massachusetts Avenue \\ Cambridge, MA 02138 \\ August 1996
}

Revision of a paper prepared for the NBER's 6th Annual East Asian Seminar on Regionalism versus Multilateral Trade Arrangements, Seoul, 15-17 June 1995. It draws on the author's paper for the World Bank Conference on Implications of the Uruguay Round for Developing Countries, Washington, D.C., 26-27 January 1995. Thanks are due especially to John Black, Richard Blackhurst, Menzie Chinn, Jane Drake-Brockman, Bernard Hoekman, Takatoshi Ito, Anne Krueger, Will Martin, Chong-Hyun Nam, David Richardson, and Dani Rodrik for helpful comments, and to the World Bank, NBER, Korea Development Institute, and the Australian Research Council for financial support. Forthcoming in Regionalism vs Multilateral Trade Arrangements, edited by $\mathrm{T}$. Ito and A.O. Krueger, Chicago: University of Chicago Press for the NBER, 1996. This paper is part of NBER's research program in International Trade and Investment. Any opinions expressed are those of the author and not those of the National Bureau of Economic Research.

(C) 1996 by Kym Anderson. All rights reserved. Short sections of text, not to exceed two paragraphs, may be quoted without explicit permission provided that full credit, including $\odot$ notice, is given to the source. 


\title{
SOCIAL POLICY DIMENSIONS OF \\ ECONOMIC INTEGRATION: \\ ENVIRONMENTAL AND LABOUR \\ STANDARDS
}

\begin{abstract}
Social policies, particularly environmental and labour issues, are not new to trade policy fora including the GATT. However, they are likely to have a more prominent role in trade policy discussions in the years ahead for the new World Trade Organization. Many developing countries perceive the entwining of these social issues with trade policy as a threat to both their sovereignty and their economies, while significant groups in advanced economies consider it unfair, ecologically unsound, even immoral to trade with countries adopting much lower standards than theirs.

This paper examines why these issues are becoming more prominent, whether the WTO is an appropriate forum to discuss them, and how they affect developing and other economies. It concludes that (a) the direct effect on developing economies is likely to be small and for some may even be positive through improved terms of trade and/or compensatory transfer payments, but (b) there is an important indirect negative effect on them and other economies, namely, the potential erosion of the rules-based multilateral trading system that would result from an over-use of trade measures to pursue environmental or labour market objectives.
\end{abstract}

\section{Kym Anderson}

Centre for International Economic Studies

University of Adelaide

Adelaide SA 5005

AUSTRALIA

kanderson@economics.adelaide.edu.au 


\title{
SOCIAL POLICY DIMENSIONS OF ECONOMIC INTEGRATION: ENVIRONMENTAL AND LABOUR STANDARDS
}

\author{
Kym Anderson \\ University of Adelaide and CEPR
}

Despite the conclusion of the Uruguay Round negotiations in 1994 and the conversion during 1995 of the GATT Secretariat into a more-influential World Trade Organization (the WTO), trade tensions between nations remain considerable. Part of the tension continues because of social policy differences across countries: differences in worker rights and standards, in human rights more generally, in technical standards of production, in natural resource and environmental policies, in animal welfare issues, in education and health policies, in support for national culture or exclusion of foreign cultural influences, and so on. Some countries have sought to use trade policy as a stick or carrot to induce other countries to adopt something closer to their social policy standards. The United States, for example, routinely does this in its dealings with China over human rights. It has also used trade policy with Mexico in pursuit of animal welfare (the famous dolphintuna case), and with Vietnam in pursuit of the interests of US families of missing-inaction soldiers.

Apparently social policy differences are becoming more important in disputes between countries. Why? Under what circumstances (if any) is trade policy an appropriate instrument for resolving such disputes? What are the implications for the global trading 
system, for regional trading arrangements, and for their interaction? What if anything should East Asian countries and perhaps APEC do about this development? These questions are addressed in this paper by focusing mainly on environmental issues and trade, since their entwining in policy circles is arguably the most controversial and the matter is already on the WTO's work agenda. Some discussion of the trade and labour standards issue also is included in the paper, partly because it parallels the trade/environment debate to some extent, partly because the United States and France would like to see it added to the WTO's agenda, and partly because it is already included in some major regional trade agreements. In fact both issues arose in a significant way in the NAFTA negotiations of the early 1990s, to the point where it appeared the US Congress was not willing to ratify that agreement without accompanying supplemental agreements on environmental and labour standards. Since the 1950s these issues also have been part of West European integration negotiations, most recently with heated debate among European Union member governments at Maastricht over a 'social charter' relating to labour standards.

The paper is structured as follows. The first section looks at why social policies in general are becoming subjected to more international scrutiny, both regionally and globally. Section two then asks why environmental issues in particular are becoming more entwined with trade policy. Section three examines the relationship between economic growth, trade, and the environment. The following section discusses the nature and extent of entwining of GATT and the environment. This is followed by some speculation on what lies ahead for the WTO in its relationship with existing and prospective multilateral environmental agreements. Section 6 is devoted to discussing GATT/WTO and labour 
standards, showing why their entwining has become an issue in the mid-1990s and how in some (but by no means all) respects the issue of trade and labour standards is similar to the trade/environment issue. Both issues have a distinct North-South dimension, which is why developing countries are becoming more concerned about them. The final section of the paper focuses on what developing countries and APEC could do in response to these developments.

\section{Why social policies are coming under closer international scrutiny}

Social policy differences across countries are to be expected. Partly they reflect per capita income differences: as communities become richer, so does their demand for social policies and higher standards. Policy differences exist also because of differences in tastes and preferences. Indeed one of the key reasons for nationhood is to bring together and distinguish one grouping of people whose preferences are more similar to each other than to those of neighbouring groups (Alesina and Spolaore 1995). In the case of environmental policies, they also reflect differences in per capita endowments of natural resources and environmental amenities. A diversity of social policies therefore contributes to differences in countries' comparative advantages in trade and therefore to the gains from trade.

As economic integration proceeds, though, pressure increases to reduce differences in social policies that have economic consequences. This has clearly happened within countries in the course of their economic development: numerous local, state or provincial policies/standards have gradually been replaced by national standards and conformance 
assessment (National Research Council 1995). The motivation is not just to reduce administrative and conformance costs. It also results from concerns in high-standards regions that costs of production for some firms and industries are higher in their region than in regions with lower standards, causing them to be less competitive. These differences become ever-more important as traditional barriers to trade and investment between regions fall (notably transport and communication costs). Harmonization of those standards could go in either direction, however, with winners and losers in each region trying to influence the outcome. And there is no reason to presume that overall national economic and social welfare will improve because of those social policies being harmonized: it all depends on how close the most influential groups' standards are to those of the median voter.

Similar forces to those intra-national ones are also at work in the international arena. There have been substantial reductions in recent decades in traditional barriers to foreign import competition, including international transport and communication costs, tariffs, and other governmental border policies that inhibit flows of goods, services, and capital across national borders. ${ }^{1}$ The resulting extra exposure of national economies to competition from abroad -- in part due to the very success of GATT in promoting trade liberalization -- has caused attention to focus more sharply on domestic policies, including cost-raising social policies and standards, that continue to reduce the international competitiveness of some firms and industries in each country (Bhagwati 1996). These harmed producers are especially likely to protest when significant new players with lower standards become competitors. This has happened increasingly during the past quarter 
century first with the growth of Asia's newly industrializing economies and then the opening up of China and numerous other transition and developing countries.

It has been suggested that one of the driving forces behind regional integration initiatives has been the tardiness of the GATT in taking up social policy issues among its large and diverse group of contracting parties (Lawrence 1995). Achieving agreement to harmonize social policies and otherwise coordinate trade- and investment-related domestic policy reforms is easier the more similar are the per capita incomes, tastes and preferences of the countries concerned. Hence we observe the formation of trade blocs more among similar than disparate economies. We also observe the inclusion of social in addition to trade policies more in integration agreements involving richer than poorer countries, presumably because (a) the demand for social policies is income elastic, and (b) barriers to trade and investment flows (both natural and governmental) between countries tend to be lower among rich countries than between them and poorer countries or among poorer countries.

When dissimilar countries have sought to join such blocs (e.g., Mediterraneans to the EC, Mexico to the NAFTA), advocates for higher standards have endeavoured to tie market access to the upward harmonization of social policies. To a considerable extent they have succeeded in doing so in the European Union. And in the case of NAFTA they were also after President Clinton came into office, to the extent that side agreements on environmental and labour standards were added to the NAFTA in the closing hours of the negotiations. 
As for trade outside these blocs, we tend to observe advocates for high standards supporting import restrictions on like products from lower-standard countries. Why? Because such restrictions simultaneously reduce opposition by local firms to the raising of standards at home and increase the incentive for foreign firms and their governments to adopt higher standards abroad (out of fear of losing market access). However, such uses of trade policy are both discriminatory and protectionist. That brings advocates for higher standards both into direct conflict with supporters of liberal world trade and into coalition with traditional protectionist interests. Fear of the latter gaining superficial respectability in arguing against trade liberalization has led to claims that 'social correctness' is becoming the New Protectionism (Steil 1994).

\section{Why environmental issues are becoming more entwined with trade policy}

The list of environmental concerns with international or global dimensions has grown rapidly in recent years. In addition to people being worried about air, water, soil and visual pollution at the local, national and regional ${ }^{2}$ levels, some of that pollution is believed to be also damaging the environment on a global scale, for example through ozone depletion and climate change. Some in rich countries are concerned that these problems will be exaccerbated as economic growth takes off in newly industrializing countries with laxer environmental standards. More and more people worry also about resource depletion, species extinction and animal welfare at the global level, regardless of national boundaries. Ongoing integration of the world economy also brings with it new health and safety concerns by consumers of imported products. Needless to say, personal 
values play an important role in debates on these issues. Hence there is considerable scope for friction between countries with different preferences, resource endowments, incomes, and knowledge about how different activities and policies affect the environment, and therefore different perceptions of optimal national and global environmental and resource policies.

Fluctuate though they might with the business cycle, these heightened concerns for resource depletion and the environment are likely to keep growing. One reason is that, even though uncertainties remain, the scientific basis for many of these concerns is perceived to be more solid now than was the case twenty years ago. Another is that both the world's population and its real per capita income continue to increase at very high rates by historical standards. Unfortunately, though, the supplies of most natural resources and environmental services are limited, and markets for many of them are incomplete or absent. ${ }^{3}$ Markets are under-developed because of disputed, ambiguous or non-existent property rights, or because of the high cost of enforcing those rights.

It is true that the more advanced economies have established institutional structures to help handle the tasks of arriving at a social consensus on what are appropriate environmental or sustainable development policies for that society, of allocating property rights, and of enforcing policies. The same is true in some traditional societies before they begin to 'modernize' and their resources come under pressure because of declining mortality rates. But it is less true in the newly 'modernizing' economies, where the world's population and consumption growth are expected to be concentrated for the foreseeable 
future. And, at the multilateral level, co-operative intergovernmental mechanisms in the environmental area have only recently begun to be formed and will take some time before they become very effective, especially where free-rider problems are rife.

So, with sufficient fora yet to be fully developed for multilateral environmental dialogue, and with the problems increasingly being perceived as urgent as new scientific evidence becomes available, there is a growing interest among environmental groups -- especially in the more advanced economies -- in using one of the few policy instruments apparently available to their governments, namely trade restrictions, to influence environmental outcomes both at home and abroad.

Environmental groups perceive trade policy as a means both of raising national environmental standards at home and abroad and of inducing countries to become signatories to and abide by international environmental agreements. On the first, these groups are aware that, unless compensated, firms will oppose the raising of domestic standards if competitors abroad are not subjected to similar cost increases. But since the loss of competitiveness can be offset by import restrictions on products from lowerstandard countries, such restrictions can at the same time remove opposition by local firms to higher standards at home and increase the incentive for foreign firms and their governments to adopt higher standards abroad. Not surprisingly, those features make trade policy very attractive to environmentalists.

On the second, with respect to international environmental agreements, a major attraction of trade measures is that they can be used effectively as sticks or carrots because they are 
relatively easy to use and are immediate in their impact. Even the threat of trade sanctions can have a rapid and persuasive effect in encouraging a country to join an international environmental agreement and subsequently to abide by its rules.

Already we have seen the use of discriminatory trade restrictions affecting particular targeted products (for example, in the Montreal Protocol on CFC substances that deplete the ozone layer). There have also been proposals to use trade sanctions against unrelated products. These aim chiefly at persuading developing countries to adopt stricter environmental standards (for example, threats to provide less open access to textile and other markets in industrial countries unless logging is curtailed or managed on a more sustainable basis).

\section{The relationships between economic growth, trade, and the environment}

The standard theory of changing comparative advantages in a growing world economy, which has been developed without consideration of environmental concerns, can readily be modified to incorporate at least some of those concerns. As espoused by Krueger (1977) and Leamer (1987), this theory suggests that when a developing country opens up to international trade, its exports initially will be specialized in primary products. This is because its stocks of produced capital relative to natural resources are comparatively low. Should those non-natural capital stocks per worker (including human skills) expand more for this country than globally, the country's comparative advantage will gradually shift to more capital- and skill-intensive activities (particularly manufactures and services). If such countries are relatively land-abundant, some of that produced capital and new or 
newly imported capital-intensive technology may be employed profitably to extract minerals or farm the land. But in most such countries the new capital will encourage the expansion of nonprimary sectors and shift these countries' comparative advantage away from primary products. Thus countries that are lacking in natural resources or that are densely populated will tend to industrialize at an earlier stage of economic development, and their nonprimary exports will tend to be more intensive in the use of unskilled labor initially. In the case of manufactures, the process of upgrading to more capital-intensive production over time leaves room in international markets for later-industrializing countries also to begin with labour-intensive export-oriented manufacturing.

If national boundaries were such that there were no international environmental spillovers, and there were no global commons, this story need be complicated only slightly to incorporate non-marketed environmental services and pollution by-products. The complication required is simply to allow for the fact that as a country's per capita income and industrial output grow, the value its citizens place on the environment increases and with it their demands for proper valuation of resource depletion and environmental degradation, for the assigning and better policing of property rights, and for the implementation of costly domestic pollution abatement policies that may induce the production and dissemination of less-pollutive technologies -- at least after certain threshold levels of income and/or pollution are reached. ${ }^{4}$ Beyond those threshold points the severity of such abatement policies is likely to be positively correlated with per capita income, with population density, and with the degree of urbanization. 
If all economies were growing equally rapidly, the progressive introduction of national environmental taxes and regulations would tend to cause pollution-intensive production processes to gradually relocate from wealthier and/or more densely populated countries to developing and/or more sparsely populated countries. ${ }^{5}$ They would also slow or reverse the growth in the quantity demanded of products whose consumption is pollutive, and more so in wealthier and/or more densely populated countries where taxes on such products would tend to be highest. If more-advanced economies are net importers (net exporters) of products whose production (consumption) is pollutive, these countries' optimal environmental policies would worsen their terms of trade to the benefit of poorer economies, and conversely (Siebert et al. 1980; Anderson 1992a). Thus even countries without (or with unchanged) environmental policies will be affected through foreign trade and investment by the development of environmental policies that accompany growth in other economies. ${ }^{6}$ The extent of international relocation of productive activities due to the raising and enforcement of environmental standards should not be exaggerated, however. Recent studies suggest the effect of such policies on comparative costs may be quite minor. $^{7}$

The story becomes more complicated, however, when account is taken of policy reactions to international environmental problems such as the global commons, species depletion or animal rights. The ban on ivory trade under the Convention on International Trade in Endangered Species (CITES) provides an extreme example: the strong comparative advantage that southern African nations had in elephant products virtually disappeared when the ban was introduced in 1989. Another is the recent ban, adopted under the Basel 
Convention relating to hazardous waste, on exports of so-called hazardous recyclables from industrial to developing countries: that ban threatens the growth prospects for recycling industries in developing countries. A third example is the proposed limitation on imports into some high-income countries of tropical hardwoods, the aim of which is to discourage deforestation. An import ban of this kind would reduce export growth in logs and perhaps sawn timber in those developing countries still well endowed with hardwood forests, while improving the terms of trade of other net importers of hardwood such as Japan, Korea and Taiwan. In addition, the Montreal Protocol on phasing out the use of ozone-depleting CFCs incorporates discriminatory trade provisions, designed to limit the relocation from signatory to non-signatory countries of industries producing or using CFCs, as well as encouraging non-signatories to accede to the Protocol. ${ }^{8}$ And there is the infamous example of the United States ban on the importation of Mexican tuna which US authorities deem to have been caught in dolphin-unfriendly nets: domestic US regulations affecting the use of dolphin-unfriendly nets on US registered fishing vessels, if implemented alone, would have boosted Mexican competitiveness in tuna fishing, but the subsequent ban on tuna imports instead reduced it. As is clear in the latter two examples, the motive for trade policy action is often a mixture of national competitiveness concerns and concerns -- especially in wealthier countries (typically not shared to the same extent by developing countries) -- for the global commons and for animal welfare.

Two facts therefore need to be recognised. The first is that there are important international environmental spillovers beyond the simple transborder ones that can be handled through negotiations between governments of affected neighbouring countries. 
Those spillovers are of two sorts: in addition to the physical damage our activities can do to the global environment regardless of the location on the globe of those activities, there are -- for want of a better term -- psychological spillovers as well. For example, I may grieve if another country's activities threaten a particular animal or plant species in its jurisdiction. Or I may grieve if I believe your desires for higher environmental standards in your country are not being recognised sufficiently by your national government (a political market failure). Controversial though such views are, ${ }^{9}$ many people perceive a need for multilateral action to reduce these spillover problems, and that is where trade policy measures enter the debate: they are seen by environmentalists as providing powerful carrots and/or sticks for attracting signatories and/or penalizing non-signatories to bilateral or multilateral environmental agreements, as well as for encouraging other countries to adopt better national environmental policies for the sake of their own citizens and environment.

The other fact that needs to be recognised is that one country's environmental policy choice is not independent of the choices of other countries. Why? Because the imposition of higher standards or pollution charges at home alters the international competitiveness of industries, in particular by harming the more pollution-intensive industries. If their competitors abroad were not subjected to similar cost-raising policies, such industries would lobby against the imposition of higher standards at home. And while it is true that the less-pollutive industries at home would benefit from higher environmental standards, they are more diffuse and so are not likely to add much support to the environmentalists' lobbying. 
It was because of this latter fact that trade policy first entered the environmental picture, back in the latter 1960s when the first wave of widespread concern for the environment began in industrial countries. As already mentioned, environmental groups perceived that, since the loss of competitiveness of pollution-intensive industries could be offset by restrictions on imports from lower-standard countries, such restrictions could at the same time reduce opposition by such industries to higher standards at home and increase the incentive for foreign firms and their governments to adopt higher standards abroad to avoid being subjected to anti 'eco-dumping' duties.

The demand for unilateral use of trade policy for this latter reason has grown over time with the internationalization of the global economy, in two ways. One is that, with the decline in traditional trade barriers (tariffs, transport and communication costs, etc.), any given environmental charge is becoming relatively more important as a determinant of international competitiveness, ceteris paribus. And the other is that, with the 1980s' deregulation of financial markets and direct foreign investment, the possibilities for firms to disinvest in high-standard countries and relocate their factories in lower-standard countries ('pollution havens') have increased markedly. Environmental groups fear this will result in governments delaying the introduction or enforcement of environmental policies -- and possibly even a lowering of standards in a 'race to the bottom' -- in their attempts to attract or retain investments and hence jobs.

Both types of environmental uses of trade policy -- unilaterally, and to increase the workability of multilateral environmental agreements -- raise potential conflicts of interest between rich and poorer countries; and the fact that discriminatory trade measures are 
increasingly being used to achieve the environmental objectives of rich countries, without regard to legitimate economic development concerns of poorer countries, increase the likelihood of environment-related trade disputes. There is even dispute over what constitutes the global commons: some would argue that a country or region should not have to bow to international pressure to preserve endangered species in their territory (or at least not without adequate compensation), while others would argue that such countries are merely the custodians of those resources for the benefit of humankind generally.

The increasing use of discriminatory trade measures to address environmental issues should concern the world at large, and developing countries in particular, for at least four reasons. First, trade policy measures typically will not be the first-best instruments for achieving environmental objectives. This is because trade sanctions or the threat of trade sanctions do not directly affect the root cause of the environmental problem. Their use in place of more-efficient instruments reduces unnecessarily the level and growth of global economic welfare as conventionally measured, and may even add to rather than reduce global environmental degradation and resource depletion. ${ }^{\mathbf{1 0}}$

The second reason for concern is that producer interest groups and some environmental groups are nevertheless finding it mutually advantageous to use environmental arguments in support of their claims for unilateral import restrictions, particularly following the costly imposition of stricter environmental standards on domestic producers. ${ }^{11}$ In this sense, the environment can provide a convenient additional excuse for raising trade barriers -- and one that is socially respectable. Unfortunately, such protectionist action 
reduces real incomes not just at home but elsewhere too, especially in developing and natural resource-abundant countries.

Third, in so far as this can lead to an escalation in trade disputes -- as is almost inevitable, especially given the North-South dimension involved and the fact that environmental uses of trade policy are inherently discriminatory -- it could be followed by retaliatory and counter-retaliatory action, the end result of which would be an undermining of the rulesbased open global trading system on which the dynamism of developing economies continues to depend.

And the fourth reason to be concerned is that there is another important sense in which aspects of environmentalism are putting at risk the global trading system. It is that, in addition to proposing the use of trade restrictions, some environmentalists also oppose trade and investment liberalization. They oppose the GATT's attempts to reduce barriers on at least two grounds: that freer trade means more output and income which they presume would mean more resource depletion and degradation of the natural environment; and that freer trade and investment encourages the relocation of environmentally degrading industries to countries with lower environmental protection standards and/or more fragile natural environments, and leads to greater transportation activity which contributes further environmental damage.

Neither of these assertions is unambiguously supported by empirical evidence, however. The first, that income increases mean greater damage to the natural environment, may be true initially for some poorer countries (in which case any additional environmental 
damage has to be weighed against the marginal economic benefits of higher incomes for poor people), but once middle-income status is reached people tend to alter their behaviour in ways that reduce pressures on the environment. A key change is in family size: higher incomes lead in time to lower population growth rates (Baldwin 1995). This, along with the increased employment opportunities resulting from trade liberalization, is likely to have a major effect in reducing the rate of environmental degradation due to population pressures in developing countries. In rural areas it means fewer people denuding hillsides to eke out a subsistence income, while in urban areas it means fewer un- or under-employed squatters in shanty towns with poor sanitation and water.

Another common behavioural change as economies open up and incomes rise is that the demand for education expands, and with more income and education comes more skillful management of all resources including the environment, and more forceful demands on governments to improve the establishment and policing of private property rights and of more stringent environmental policies (see footnote 4 above). As well, the political cost of implementing such policy reforms tends to fall because of increased opportunities for businesses to meet stricter standards by acquiring more and cheaper environmentally benign production processes and products from abroad. One might therefore expect that as trade and investment liberalization leads to upward convergence in incomes around the world, there would be an upward harmonization of environmental standards (Casella 1996). That realization points to the inappropriateness of the blanket call by some environmental groups for trade liberalization to follow the upward harmonization of standards, since liberalization may in fact induce harmonization. 
And third, the increase in the value of poor people's time in developing countries will alter household activities in another way which is especially important for the environment. It is that the relative price of wood (in terms of time spent gathering it) as a source of household fuel rises. Since about three quarters of the timber harvested in developing countries is used as household fuel, this change could have a major beneficial impact in reducing deforestation and $\mathrm{CO}_{2}$ levels.

The other major assertion by environmentalists, that the global environment is necessarily harmed by the relocation of production following trade and investment liberalization, also is questionable. We know from the law of comparative advantage that not all industries will be relocated from rich to poor countries when the former's trade barriers are lowered: some industries in the North will expand at the expense of those industries in the South, and conversely. In any case, it should not simply be assumed that relocating some production to the South necessarily worsens the environment. Recent preliminary examinations of the likely environmental effects of reducing government assistance to two of the North's most protected industries, coal and food, reveal that in both cases the global environment may well be improved by trade liberalization, especially if complementary environmental policies are in place (Anderson 1992b, Steenblik and Coroyannakis 1995). Nor need the risk of environmental damage from transport activity increase with trade reform. The lowering of import barriers to processed primary products, for example, would allow more raw materials to be processed in resource-rich countries, so reducing the bulkiness of shipments. But evidently many more empirical studies will be required before the more extreme environmental groups alter their 
perception of and publicity against multilateral trade reform as an environmentally unfriendly activity.

\section{The GATT/WTO and the environment}

How 'green' are the rules of the GATT and how have they been adapted over time? ${ }^{12}$ From the outset the GATT has been a conservationist institution in the sense that its purpose has been to reduce trade barriers and thereby the inefficiency in the use of the world's resources.

The heart of the GATT, agreed to by 23 original contracting parties in 1947 and since then by another 100 or so countries, is the nondiscrimination requirements of Articles I and III. These obligate parties to treat imports from any GATT contracting party no less favourably than other imports (the 'most-favoured-nation' requirement) and no less favourably, after border taxes are paid, than similar domestic products (the 'national treatment' requirement).

Article XX provides exceptions to these general rules, however, including provisions for some environmental regulations. Specifically, parts (b) and (g) of Article XX allow trade restrictions "necessary to protect human, animal, or plant life or health" and "relating to the conservation of exhaustible natural resources if such measures are made effective in conjunction with restrictions on domestic production or consumption", subject to the requirement that such restrictions "are not applied in a manner which would constitute a 
means of arbitrary or unjustifiable discrimination between countries where the same conditions prevail, or a disguised restriction on international trade". The latter has been interpreted to mean that the measure must be primarily for a conservation purpose (rather than for a mixture of motives) and must be necessary in the sense of being the least GATT-inconsistent measure available. These provisos have ensured that the Article has been rather narrowly interpreted, which is partly why some environmental groups have felt further greening of the GATT is required (Charnovitz 1991; Esty 1994). But there is nothing in the GATT that prevents a country adopting production or consumption measures to offset environmental externalities associated with either of those sets of activities. And since trade itself is almost never claimed to be the root cause of an environmental problem, supporters of the institution see little need to consider trade measures as part of the solutions to those problems.

As already mentioned, widespread public interest in trade and environmental issues first surfaced in rich countries in the late 1960s/early 1970s. At that time concern focused mainly on industrial pollution within and between neighbouring advanced economies. The foreign trade and investment issues raised at that time were centred on how the imposition of stricter pollution standards at home than abroad might damage the international competitiveness of the home country's firms, and how to avoid such damage through border protection measures.

Where the environmental damage caused by production is purely local, the calls by disadvantaged firms for trade restrictions or subsidies to offset the decline in their international competitiveness, because standards have been raised, has no economic logic: 
such assistance would tend to offset the desired effect of limiting by-product pollution. ${ }^{\mathbf{1 3}}$ Nor is it reasonable to conclude that other countries are engaging in 'eco-dumping' if the imports they are able to supply are produced with laxer environmental standards, if those lower standards are consistent with the preferences and natural resource endowments of those exporting countries (e.g., because those countries are poorer and/or less densely populated and less urbanized). Even so, claims for protection against 'eco-dumping' have political appeal and may result in higher import barriers or export subsidies than would otherwise be the case in advanced economies. Leading up to the UN Conference on the Human Environment, held in Stockholm in June 1972, the GATT Secretariat produced a background paper on those issues (GATT 1971), and a Working Group on Enviromental Measures and International Trade was established. But no significant changes to the GATT occurred during the Tokyo Round as a result of these concerns being expressed, and it was two decades before the Working Group met for the first time.

Trade policy actions are more likely to occur, and to be more difficult to dismiss as inappropriate, when environmentalists in such countries view particular damage to the environment as unacceptable regardless of the nation in which the damage occurs. This case is even more problematic if the damage is not just psychological (as with animal rights) but also physical, for then the relocation of production to a country with laxer environmental standards may worsen animal welfare, or the environment at home, in addition to reducing the profitability of the home firms. The US-Mexico dispute over the use of dolphin-unfriendly nets by tuna fishermen again comes to mind. In that case the GATT ruled against the US ban on imports of tuna from Mexico, partly because the ban 
did not discriminate according to which type of net was used -- as it cannot, because an aspect of the production process rather than the final traded product itself is what is considered objectionable. The GATT panel ruled against the ban because to do otherwise would have created a huge loophole in the GATT for any country unilaterally to apply trade restrictions as a means of imposing its environmental standards on other countries. Such a loophole would work against the main objective of the multilateral trading system which is to provide stable and predictable nondiscriminatory market access opportunities through agreed rules and disciplines and bound tariffs on imports.

Following a lull in interest brought on by the economic disruptions of the 1973-82 oilshock period, the current wave of public concern for the natural environment, leading up to and following the United Nations Conference on Environment and Development held in Brazil in June 1992, is much more intense, more widespread, and likely to be sustained and to affect a much broader range of countries than was the case prior to the latter 1980s. The Uruguay Round agenda was set by 1986 , before the current wave had built up, so the trade/environment issue was not a separate item for negotiation. Nor was there an environmental impact assessment of the Round as a whole. However, the Working Group on Environmental Measures and International Trade that was formed in 1971 was activated for the first time in 1991 and has met frequently since then. As well, several of the Uruguay Round agreements contain provisions that relate to the environment and build on Articles in the General Agreement. 
The most fundamental provision in the Round is in the Preamble to the agreement to establish the World Trade Organization, which refers to the WTO's objective as enabling all contracting parties the maximum opportunities for:

\begin{abstract}
"expanding the production and trade in goods and services, while allowing for the optimal use of the world's resources in accordance with the objective of sustainable development, seeking both to protect and preserve the environment and enhance the means for doing so in a manner consistent with their respective needs and concerns at different levels of economic development".
\end{abstract}

To give initial effect to that, a decision was taken on trade and environment by ministers meeting in Marrakesh in April 1994 to sign the Final Act of the Uruguay Round. They agreed to establish a Committee on Trade and Environment to report to the first biennial meeting of ministers (probably in late 1996). The other main features of the Uruguay Round agreements with environmental provisions relate to technical barriers to trade, sanitary and phytosanitary measures, and the agreements on subsidies and counterveiling duties and on trade-related intellectual property rights. Overall, the trade liberalization to result from the Uruguay Round is likely to conserve resources and reduce environmental degradation rather than be unfriendly to the natural environment (see Anderson 1995 for details).

\title{
5. GATT/WTO and multilateral environmental agreements
}


The other way in which trade policy is being called upon to help achieve environmental objectives has, as mentioned above, more validity. It is as a carrot or stick to entice countries to sign and abide by multilateral environmental agreements. In the case of combatting global environmental problems such as ozone depletion or climate change, the free-rider problem arises. One of the more obvious and possibly more cost-effective ways to reduce the free-rider problem is to write trade provisions into the agreement, as was done in the 1987 Montreal Protocol on reducing the use of CFCs and halons to slow ozone depletion. To date no GATT contracting party has formally objected to that use of trade policy. Nor have they to the bans on trade in ivory and rhino horn and tiger products that are part of the Convention on International Trade in Endangered Species (CITES), or to the trade provisions in the Basel Convention on trade in hazardous wastes. Conflicts may well arise in the future, however, if trade provisions are drafted into more contentious multilateral environmental agreements (e.g., to impose a global carbon tax). That is why this matter figures importantly on the agenda of the new WTO Committee on Trade and Environment. Discussions so far in the GATT/WTO have centred around the idea of providing waivers on a case-by-case basis or, alternatively, of providing an "environmental window" for multilateral environmental agreements within the GATT exceptions clause (Article XX).

To help assess the appropriate role for trade policy in multilateral environmental agreements, it is helpful to recall that supporters of trade liberalization and of environmental protection share a common goal: to improve social welfare. They also share a common problem: the need to foster multilateral cooperation to fully achieve that objective, because in each sphere (the economy, and the environment) there is 
considerable and increasing interdependence among nations. But the two groups differ in the important respect that supporters of liberal world trade have understood its virtues for two centuries and have been active for more than 50 years in building institutions such as the GATT and WTO to help achieve their goal, whereas widespread concerns about the environment are relatively new and supporters of environmental protection entered only recently as significant players in international policy arenas.

Understandably, supporters of liberal trade and the GATT/WTO resent the encroachment of these 'new kids on the block' onto what they perceive as their hard-won territory, especially when they genuinely believe that reducing trade barriers is likely to be environmentally friendly and consistent with sustainable development in the long run in the sense that it allows the world to use its resources more efficiently. ${ }^{14}$ Equally, advocates for greater environmental protection are frustrated that international agreements as important as those resulting from the GATT's recent Uruguay Round can be implemented without being subject to environmental impact assessments or environmental safeguards.

Clearly there is scope for greater understanding and altered strategies on both sides. More than that, there is the distinct possibility that, by working together, both groups' objectives will be further enhanced -- a 'win-win' outcome. Some observers believe that it may ultimately require a world environment organization to set rules, incorporate existing international environmental agreements and negotiate new ones, monitor compliance, and settle disputes over environmental policies-in the same way that the GATT has presided over trade rules and policies for the past five decades (Esty 1994). And just as the 
GATT/WTO strengthens the capacity of governments to resist the demands of domestic vested interest groups seeking higher import taxes, so a world environment organization may help governments resist interest group demands to set low environmental standards (Deardorff 1995). The advantage of a World Environment Organization for traders, Esty argues, is that it could redirect environmentalists' attention away from trade policies and towards ensuring the implementation of more efficient policy instruments for achieving environmental objectives, allowing both sets of policies to contribute more effectively toward the common goals of sustainable development and improvement in the quality of life. Even so, the issue of whether the WTO or the WEO would have precedence would need still to be resolved. It is noteworthy that the side agreement to the NAFTA gives a surprising (to me, given that it is a trade agreement) degree of precedence to environmental concerns relative to trade concerns. What needs to be recognised is that where the two are in conflict, achieving the optimal welfare-maximizing outcome requires both to compromise somewhat.

Thus without doubt the trade policy community needs to be involved in the negotiating of multilateral environmental agreements that are likely to include trade provisions, and to develop criteria by which WTO members could assess in advance the extent to which trade restrictions within such agreements are acceptable. Some of the relevant criteria were enunciated at UNCED. It is important, first, to ensure that trade provisions are strictly necessary and effective in achieving the environmental objectives involved. For the reasons outlined earlier, there will often be an alternative, more effective instrument than trade restrictions. Where trade instruments are required in the absence of superior policy measures, they should be used only in proportion to the size of the associated 
environmental problem and should be the least trade restrictive measure available. The measures ought to be transparent and not be protectionist in impact, and where possible be consistent with both the GATT principles of non-discrimination (most-favoured-nation and national treatment) and the key environmental principles such as the polluter pays and the precautionary principles. If those conditions are met, WTO members would be unlikely to object to the use of trade measures in multilateral environment agreements (witness the absence of objections by GATT contracting parties to the trade provisions in the Montreal Protocol and the Convention on International Trade in Endangered Species). Hence even the possible need to use trade provisions in multilateral environmental agreements does not provide sufficient reason to amend GATT Article XX to allow in the list of exceptions the use of trade measures for environmental protection.

\section{GATT/WTO and labour standards}

An even more questionable entrant onto the WTO's potential agenda than the environment, and one that has an even clearer North-South dimension, is the issue of labour standards (Bhagwati and Dehejia 1994). Government and/or labour union actions in setting minimum labour standards are often considered necessary to reduce the risk of exploitation of (particularly low-skilled) workers by capitalists. As with environmental standards, labour standards differ between countries and tend to be lower and/or enforced less in developing countries. The direct effect of such things as shorter working weeks, higher overtime pay, longer annual leave, safer and healthier working conditions, etc. may be to raise worker welfare, but they also raise the cost of employing labour -- otherwise they would have been adopted voluntarily and so there would be no need for government 
or union action. ${ }^{15}$ They are therefore similar to other taxes on production that differ across industries in that their indirect effects need to be considered as well (Ehrenberg 1994). Specifically, they effectively make (particularly low-skilled) labour scarcer. That tends to raise the cost of production in labour-intensive industries most in high-standard countries, thereby reducing the capacity of those industries to compete with producers in low-standard countries while enhancing the capacity of other industries to so compete, along Rybczynski (1959) lines.

The owners of firms in harmed industries can respond to demands for higher labour standards by lobbying against their imposition and/or by demanding protection from imports from lower-standard countries until the latter are raised. Thus one country's choice of standards is not independent of the choices of other countries, nor is the country's trade policy independent of that relationship. As with environmental standards, the demand for unilateral use of trade policy for this reason has grown over time with the internationalization of the global economy: the decline in traditional trade barriers has ensured that any given cost-raising standard is becoming relatively more important as a determinant of international competitiveness, and the deregulation of direct foreign investment abroad has increased the possibilities for firms to relocate their factories from high- to lower-standard countries.

To what extent is there a parallel claim with the environment issue for placing labour standards on the WTO's agenda because of international spillovers? Many economists would say there is none, because they perceive no physical spillovers of the globalwarming or ozone-depleting kind. At least one minor one may be present in some times 
and places though. It is the effect of high standards for low-skilled workers in attracting unwanted migrants from less-developed economies across borders that may be difficult to police. ${ }^{16}$ Furthermore, there is the possibility also of psychological international spillovers. People may grieve because of abuse of what they perceive as worker rights or poor working conditions abroad just as they may for their low environmental standards or abuse of human rights generally. But, again as with the environment, while that may provide justification for action of some sort at the international level, there are only very limited circumstances in which multilateral trade measures are worthy of consideration as sticks or carrots for encouraging other countries to raise their standards. One is in cases where, as happened in the NAFTA negotiations, there comes a point when significant negotiating parties refuse to enter further multilateral trade negotiations unless labour standards are on the agenda. Should that happen, a judgement would have to be made by the other negotiating parties as to whether it would be worth continuing under such a condition. Another is when aggrieved high-standard countries can find no lower-cost ways to influence the policies of lower-standards countries, but even there the psychological benefits to the North may be insufficient to warrant the costs to consumers and exporters in the high-standard countries (not to mention the net costs to the affected low-standard countries). And a third possible circumstance is when there might otherwise be a reluctance to raise one's own national standards so as not to erode the competitiveness of those domestic industries harmed by an increase in the gap between labour standards at home and abroad.

The concern in high-standard countries ostensibly is not so much the average wage level difference but rather such things as occupational health and safety standards, worker 
rights to form unions and seek a minimum wage level and other improved conditions of employment, the use of child or prison or forced labour, and the derogation from national labour laws in export processing zones. The United States and France, for example, were at pains to make clear at Marrakesh that their push for the WTO to consider trade/labour issues was very much focussed on differences in labour standards other than wages. Human rights activists and development NGOs often add support to union calls for higher standards in developing countries, believing that it would improve the quality of life there -- even though in fact the raising of labour standards in the formal sector is more likely simply to drive employment into the informal sector (where labour standards are even lower), and/or to lengthen the queues of unemployed people seeking high-paid, highstandard formal sector jobs. ${ }^{17}$ In the case of young women displaced from their jobs by higher labour standards, they may to have to marry and bear children earlier than otherwise, or even to enter prostitution, in order to survive. ${ }^{18}$

As with environmental standards, traditional protectionist forces in high-income countries are prompt to support any such calls for import restraint by high-standard countries against goods from lower-standard countries. They sometimes bolster their case by quoting simple trade theory (the Factor-Price Equalization and Stolper-Samuelson Theorems) in support of their argument that liberal trade leads to factor price convergence and in particular to a drop in low-skill wages in high-wage countries -- even though those theorems have been shown to be not very robust when more than two countries, goods and factors are involved (Falvey 1995) and are not supported by empirical simulation results of trade liberalizations such as the Uruguay Round. ${ }^{19}$ There is also a risk that 
support for openness in low-standard countries could come under challenge if those who lose from the forced raising of those standards lobby domestically against their country's exposure to other societies through having a liberal trade regime.

The International Labour Organisation has been writing labour standards for 75 years. Why has this issue suddenly become entangled with the GATT/WTO and trade policy issues? In fact the entwining of trade and labour standards is not new, ${ }^{\mathbf{2 0}}$ but it raises its head mainly when the trading system is in the news and particularly if labour markets are in trouble at the time. It became an issue when the International Trade Organization was being conceived in $1947,{ }^{21}$ and again at the end of the Tokyo Round, and now once more as the WTO establishes itself and the Uruguay Round starts to be implemented at a time of poor labour market performance in industrial countries (with unemployment above 10 per cent in Europe and relative earnings of unskilled labour in the United States deteriorating).

Over time, though, the issue is coming under increasing discussion. This is partly for the reason mentioned earlier of declining trade and investment barriers which mean that costraising standards become relatively more important as determinants of international competitiveness and plant location. But a further implication of falling communication costs is that citizens of high-standard countries are increasingly able to get information on labour (and environmental) standards in other countries. That, together with the evergreater sense of integration among the world's people (the 'global village' idea), allows and encourages the concern for human rights to spread beyond national boundaries, a tendency that might therefore be expected to continue indefinitely as global economic 
growth and integration proceed. Around that upward trend in concern will be fluctuations that are opposite to the business cycle: the worse the labour market is performing in highwage countries (especially in the lower-skill categories), the more likely it is that imports from low-wage countries will be blamed ${ }^{22}$-- notwithstanding clear evidence that such imports are at most only a very minor contributor (Lawrence 1994; Burtless 1995; Tyers and Yang 1995). And that likelihood is exacerbated by the computer and information revolutions which, together with other forces, are increasing the demand for skilled relative to unskilled workers (Wood 1994).

Another reason why the labour issue has become more prominent in the multilateral trade arena once again is because it has succeeded recently in penetrating regional integration agreements. Specifically, there is the inclusion of a Protocol on Social Policy annexed to the Treaty of Maastricht signed by EU member governments in February 1992 (Sapir 1996). As well, it became the subject of a side agreement to the NAFTA in 1993 -- a price President Clinton paid to buy off opposition from labour groups to the NAFTA's passage through the US Congress. Having been encouraged by their success in those regional economic integration settings, and before that in some minor trade and investment agreements in the 1980s (see Lawrence (1994) for details), the advocates for that side agreement are now, like the environmental lobby groups, seeking to have an influence at the multilateral trade level. In both situations, the desire of the GATT's contracting parties to conclude, ratify and implement the Uruguay Round agreements on trade liberalization was to a considerable extent simply being used opportunistically by these groups to further their own causes, despite the tenuous connection of those causes with trade. Their 
relative success to date is in large part because their causes have superficial popular appeal, while the downside in terms of the potential risk to the global trading system is far from obvious to the layperson.

To conclude this section, it is instructive to examine the progress of labour policies in the sub-global arena of the EU. A recent assessment by Sapir (1996) concludes that in Europe there has always been the optimists who believe economic integration breeds greater economic growth and equality of social policies (led by the Ohlin Report to the ILO at the time of the formation of the EEC -- see International Labour Organisation (1956)), and the pessimists who believe upward harmonization needs to be imposed on lower-standard countries to improve citizens' conditions there and avoid "social dumping" though trade. In practice, relatively little has been imposed effectively on the poorer member countries of the EU; the most that has been agreed to is the adoption of some minimum standards and mutual recognition. Yet standards have risen rapidly with the acceleration of income growth in the poorer EU countries. Where standards have risen even faster than normal they have been accompanied by large "economic and social cohesion" payments from Brussels. However, since explicit side payments are not as readily available at the multilateral level, and since the number and diversity of lower-standard countries is far greater globally than within the EU, the likelihood of major action through the WTO (much less the ILO or a WEO) seems slight.

7. What could and should developing countries and APEC do about these developments? 
The demands for greater harmonization of domestic policies for competitiveness reasons, coupled with the greening of world politics and the growing interest in worker and other human rights beyond national borders, are likely to put the WTO and trade policy under pressure to perform tasks for which they were not designed and are not well suited -- and at a time when the WTO needs first to consolidate its role in the world and ensure the implementation of the Uruguay Round before moving into these more thomy issues that are only peripherally connected with trade. ${ }^{23}$

The pressure on the WTO to become more entwined with issues of environmental and labour standards is and should be of considerable concern to developing countries. The reason is not so much that the imposition of higher standards themselves would be costly to them. In fact middle-income, mid-standard countries may well be net beneficiaries if low-income, low-standard countries were required to raise their standards more than them to reach minimum acceptable levels. Even the negative direct effect for low-income economies of having to raise their standards could be offset somewhat, at least for the most labour-abundant poor countries, by a terms of trade improvement if many countries were to raise their labour standards multilaterally and if that reduced the global supply of low-skilled labour time. Nonetheless, people in developing countries are suspicious of the motives of OECD countries, and object to what they perceive as social imperialism and a denial of their national sovereignty.

While they are not being targeted per se, the fact is that such standards tend to be applied less in developing countries because they are poorer. That, together with the fact that their 
comparative advantages often are in labour-, natural resource- and pollution-intensive industries, means those countries are vulnerable either to being pressured to enforce stricter standards and/or to facing less market access for their exports to stricter-standard countries. Furthermore, should the use of trade policy to try to harmonize standards upwards lead to trade retaliation and counter-retaliation, the end result could be a weakening of the multilateral trading system on which developing countries are coming to depend increasingly as they liberalize their economies. One possible consequence is that developing countries could seek refuge from anti- (eco or social) dumping duties via association with or accession to the EU or NAFTA, where they might expect to receive greater compensation for raising their social standards. In such cases, any net gain they might enjoy could well be at the expense of excluded developing countries.

However, since the entwining of these social issues with trade policy is more likely to tighten than to disentangle in the forseeable future, the question arises as to how developing countries and forums such as APEC ought to respond. One response is to point out that industrial countries had lower standards at earlier stages of their development and that, since developing countries have contributed a disproportionately small amount per capita to global environmental problems such as the greenhouse effect, they should be compensated for contributing to their solutions rather than have that contribution demanded of them under threats of trade sanctions. Compensation would be even more justified in cases where industrial countries are demanding responses by other countries to reduce the psychological international spillovers mentioned earlier. 
Another response by developing countries is to disseminate more widely the sound arguments for not using trade-restrictive measures to achieve environmental or labour objectives: that differences in standards are a legitimate source of comparative advantage in so far as they reflect differences in resource endowments and societies' preferences and ability to afford the good things in life; that standards rise with per capita income and liberal trade promotes income growth; that theory and empirical evidence provide little reason to expect that differences in standards contribute significantly to differences in costs of production and hence to trade and investment patterns, nor that downward harmonization of standards (a "race to the bottom") is occurring; ${ }^{24}$ that if freer trade were to worsen welfare of, say, low-skilled workers, adjustment assistance programs such as retraining subsidies provide much cheaper solutions than trade restrictions, as do nontrade measures such as labelling ('dolphin-friendly tuna', 'made with unionized labour') that allow consumers to exercise their preferences through the market; that the GATT rules-based multilateral trading system is threatened by the risk of environmental or labour groups being captured by traditional protectionist groups in high-standard countries, and by the risk of resulting trade restrictions and pressure to involuntarily raise standards being used by protectionist groups in lower-standard countries to argue against their countries' export-oriented development strategy.

Helpful though such argumentation could be, more dialogue and compromise between high-income and developing countries is likely to be needed. One suggestion is the following. If developing countries were to commit themselves to enforcing minimum standards and to raising those standards over time according to a specified schedule, in 
return for gradual improvements in OECD market access, vocal interest groups in highincome countries would be less able to deny that improvements in social standards are positively related to income and trade growth. That would be using trade policy as a carrot rather than a stick. Likewise, if developing countries were seen to be enforcing reasonable standards especially effectively on their foreign investors, concerns about capital outflows to "pollution havens" or "cheap labour havens" and the consequent loss of jobs in highstandard countries would be less justifiable. Alternatively or additionally, developing countries could transfer the onus back to high-standard countries to insist their firms accede to the same high standards when they invest in developing countries as in moreadvanced economies. And anxiety over deforestation could be reduced if developing countries were able to demonstrate they can police restrictions on felling and are prepared to do so in return for adequate compensation in the form of greater access to OECD markets and/or aid (e.g., via the UNDP/UNEP/World Bank Global Environment Facility administered by the World Bank).

A more controversial suggestion has been made by Rodrik (1994). He believes a case can be made for high-standard countries to take action against a trading partner if trade with that country violates a widely held social standard (i.e., one that is accepted by export and consumer interests in those countries in addition to the aggrieved import-competing producers and environmental/labour groups). The case rests on the point that an erosion of confidence in the 'fairness' of the trading system may ultimately be more costly to the world economy than the action against the offending trading partner. He suggests that the Safeguards Agreement of the Uruguay Round could be broadened to allow a 'Social Safeguards' clause whereby in such cases a country could restrict the offending imports 
and compensate the trading partner. Rodrik recognises that this could do more harm than good (not least because it would formalize a link between trade policy and social standards). Even so, he argues that its merits need to be weighed against the other options available to developing countries to minimize the damage from the encroachment of social issues into the trade policy domain. The sobering history of abuse of the GATT's other safeguards clauses, though (see Finger 1995), leaves little room for enthusiasm for this proposal to amend the Uruguay Round's Agreement on Subsidies and Countervailing Measures.

Finally, what about the role of APEC? Since a complete decoupling of social issues from trade policy seems unlikely in the foreseeable future, it is important for developing countries to consider what principles ought to govern the design of trade policies and trade-related environmental and labour policies to ensure equitable and sustainable development. Several have been mentioned above in passing. Even if developing countries were simply to discuss such a list with higher-standard countries, the resulting dialogue may itself be productive in diffusing some of the concerns expressed by environmental and labour groups (Zarsky and Drake-Brockman 1994). APEC, with its diffuse but relatively small membership, provides an obvious forum for such discussion before the much larger WTO membership debates the issues. In the same spirit, APEC might also begin to monitor trade-related environmental measures as part of its overall compilation of trade impediments in the Asia-Pacific. As well, it might actively seek, as a priority in its trade facilitation and liberalization initiatives launched at Bogor in November 1994, the removal of trade policies that incidentally harm the environment -- 
again, providing a regional example for what might eventually be achievable globally through the WTO.

${ }^{1}$ These reductions are reflected in the fact that the volume of merchandise trade has been growing nearly twice as fast as the volume of merchandise output globally (3.9 compared with 2.1 per cent per year during 1980-92), and trade in commercial services has grown even faster (raising its share of global exports of goods and commercial services from 17 to 21 per cent during 1980-92 -- see GATT 1994). Direct foreign investment, meanwhile, has grown nearly twice as fast as international trade globally over the past decade or so, following the deregulation of many countries' financial markets and the revolution in communications and data transmission.

${ }^{2}$ Trans-border pollution issues affecting adjoining countries of a region are not discussed in what follows since they are usually resolved by intergovernmental agreement without having to resort to trade policy measures, the free-rider problem being absent because of the small number of countries typically involved.

${ }^{3}$ This does not apply equally to all natural resources and environmental services of course. The doomsdayers such as Meadows et al. (1972) have been shown to be spectacularly wrong in predicting the exhaustion of minerals and energy raw materials, for example, because they have failed to take into account economic feedback mechanisms. Beckerman (1992) notes that the cumulative world consumption of many minerals during the past quarter century exceeded 'known reserves' at the beginning of the period, yet today's revised 'known reserves' nevertheless exceed those of twenty five years ago! The same cannot be said for tropical hardwoods and some fish species, however, although in these cases there is scope to move further from the current 'hunter/gatherer' technology to 
using land or water more intensively in planting trees for timber or practicing aquaculture in the same way as agriculture uses land to produce most other forms of food and fibre.

${ }^{4}$ Recent papers reporting evidence in support of the claim that the demand for implementing and enforcing pollution abatement policies is income-elastic include Radetzki (1992), Grossman and Krueger (1993, 1995), Seldon and Song (1994), and Grossman (1995). See also Deacon and Shapiro (1975) on the correlation between income levels and voter attitudes toward environmental priorities. Studies aimed at explaining this transition (sometimes called an environmental Kuznets curve) are now beginning to emerge. Beltratti (1995) seeks to explain it in terms of transitional dynamics of endogenous growth models, while Jones and Manuelli (1995) provide a positive political economy model.

${ }^{5}$ The term 'pollution-intensive production processes' should be broadly interpreted to include activities such as mining in pristine areas or leisure services that may attract undesired local or international tourists. The presumption is that industries are not affected equally by the progressive raising of environmental standards and charges, for otherwise there would be little change in the pattern of a country's trade.

${ }^{6}$ Similarly, if as they grow economies were to institutionally shorten working hours per week, raise wages for time worked outside those hours, or otherwise increase the cost of labour time in attempting to raise labour standards, that would speed the transformation of those economies' comparative advantages away from labour-intensive activities. If those institutional changes affected mainly unskilled labour, the competitiveness of less 
developed economies in unskilled labour intensive products would strengthen even faster -- see Section 6 below.

${ }^{7}$ See, for example, Leonard (1988), Low (1992) and Jaffe et al. (1995). As well, Tobey (1990) finds little evidence of actual changes in patterns of trade specialization in response to the imposition of environmental regulations since the 1960s. However, as noted by Hoekman and Leidy (1992), the absence of changes in trade patterns may be because import barriers were raised to offset any decline in the competitiveness of affected industries.

${ }^{8}$ For details of the Montreal Protocol see, for example, Benedick (1991) and Enders and Porges (1992). A list of the other major international environmental agreements with trade provisions is provided in GATT (1992, Appendix 1) and Esty (1994, Appendix D).

${ }^{9}$ Some would argue that psychological spillovers are less worthy of consideration than physical spillovers, not least because they are less measurable and hence less 'objective'. Hence the scope for traditional protectionists 'capturing' environmentalistsconcerned with psychological spillovers is considerable. Others would counter that there is so much uncertainty about the extent and effects of physical spillovers that they too are subjective and hence are qualitatively no different from psychological spillovers. Both exist in people's minds, and there is no reason a priori to presume that one is more important than the other in some 'willingness-to-pay' or popularity sense.

${ }^{10}$ The ban on ivory trade again provides a case in point. By lowering the value of elephant products, the ban reduces the incentive for rural Africans to tolerate elephants trampling their crops and so ultimately could result in more rather than less culling of elephants in some areas. In other areas, the ivory trade ban has reduced the value of the animal so 
much that it is no longer profitable to cull the herd. An unfortunate consequence is that bushland in national parks is being decimated by the increased number of elephants, which is of course endangering other species (Barbier et al. 1990).

Even the threat of trade restrictions can be environmentally counterproductive. The talk of European import bans on tropical hardwood logs (together with tariff escallation on timber product imports) has encouraged Indonesia to ban log exports. But since felling has been allowed to continue, this policy has lowered the domestic price of logs and thereby raised effective assistance to Indonesia's furniture and other timber-using industries to extremely high levels (GATT 1991, p.127). At that lower log price and with possibly lower-quality saw-milling techniques it is not surprising that less of each tree is now used, leading possibly to nearly as many trees being felled as prior to the log export ban.

${ }^{11}$ See the discussion in Hillman and Ursprung (1992) and Hoekman and Leidy (1992), as well as the empirical evidence analysed by Van Grasstek (1992) of voting behaviour of U.S. senators.

${ }^{12}$ For detailed legal assessments, see for example Farber and Hudec (1996), Hudec (1996) and Esty (1994).

${ }^{13}$ See, for example, Baumol (1971), Siebert (1974) and Walter (1975, 1976). Such protection from import competition cannot be justified on economic efficiency grounds (nor for that matter on environmental grounds), because the environmental policy is aiming to eliminate an unjustifiable (implicit) subsidy arising through undervaluation of environmental resources, rather than to add an unjustifiable tax (Snape 1992). 
${ }^{14}$ See the literature review in, for example, Ulph (1994). Liberal traders should acknowledge, however, that opening up to trade can lead to over-exploitation of commonproperty resources (e.g., via deforestation of tropical forests) in the absense of adequate property rights, environmental charges, and/or policing, in which case there may be a second-best case for restricting trade until those problems are resolved (Chichilnisky 1994). In such cases all other distortions/market failures need to be corrected at the same time as trade is being liberalized in order to achieve unequivocal global welfare improvement. Even then, theory tells us that some countries may be made worse off and the environment may still be harmed (Copland and Taylor 1995).

${ }^{15}$ So-called neo-institutionalists argue that higher labour standards would raise worker productivity (see, e.g., Hanson 1983, pp. 53-63), but it is reasonable to assume firms will have already recognised any such possibilities and incorporated them in their work practices. If not, the first-best role for government is to subsidize the provision of information about those opportunities.

16 My thanks go to David Richardson for offering this suggestion. Needless to say, the first-best response to such a possibility may be to adopt measures to reduce illegal immigration.

${ }^{17}$ This could easily be shown using a Harris-Todaro type of model as modified, for example, by Corden and Findlay (1975). The consequences of raising labour standards in a multi-good, multi-country world can be quite complex and sometimes counter-intuitive, depending on the assumptions adopted. See the excellent theoretical analysis of several possibilities by Brown, Deardorff and Stem (1996).

${ }^{18}$ I am grateful to Anne Krueger for suggesting this possibility. 
${ }^{19}$ In their recent simulation work, Francois, McDonald and Nordstrom (1995) found real wages in all country groups to increase as a result of implementing the Uruguay Round. Using a similar global CGE model, Tyers and Yang (1995) found through both backcasting and projecting forward that expanding imports from Asia do contribute to wage dispersion and possibly lower real wages and/or unemployment in the US and EU, although only to a minor extent. Significantly, they also found that restricting imports from Asia would be an ineffective response since its impact through contracting the global economy is to lower real rewards to all types of labour in industrial countries.

${ }^{20}$ The history is patchy but goes back more than a hundred years (Hanson 1983, p. 11 and Charnovitz 1987). The text of the GATT itself mentions labour only briefly, in Article XX(e) which allows contracting parties to exclude imports of goods produced with prison labour.

21 Article 7 of Chapter II of the 1948 (Havana) Charter of the International Trade Organization addresses the issue as follows: "The members recognise that unfair labour conditions, particularly in the production for export, create difficulties in international trade, and accordingly, each member shall take whatever action may be appropriate and feasible to eliminate such conditions within its territory." See Charnovitz (1987, pp. 56667).

${ }^{22}$ This is the opposite to the case of the environment, concerns for which tend to fluctuate pro-cyclically.

${ }^{23}$ The suggestion has been made, for example, that the WTO become active in monitoring and enforcing agreed minimum social standards. That presumably would involve environmental and labour standards being reviewed as part of the GATT/WTO regular 
Trade Policy Reviews. Given that the WTO's TPR mechanism is already stretched to its limit in covering even the major trade policies of contracting parties, such an addition to its work load would require a very substantial addition to its resources -- not to mention the extra burden on those employed in national capitals when the reviews are under way. An even greater potential increase in workload would result for the WTO's dispute settlement mechanism.

${ }^{24}$ Surveys of the relevant theory can be found in Bhagwati and Srinivasan (1996), Wilson (1996) and Brown, Deardorff and Stern (1996). For empirical evidence, see for example Tobey (1990), Low (1992), Jaffe et al. (1995), and Levinson (1996) on environmental standards and Krugman and Lawrence (1993), Bhagwati (1995), and the World Bank (1995) on labour standards. 


\section{References}

Alesina, A. and E. Spolaore. 1995. 'On the Number and Size of Nations', NBER Working Paper No. 5050, Cambridge MA, March.

Anderson, K. 1992a. "The Standard Welfare Economics of Policies Affecting Trade and the Environment", Ch.2 in The Greening of World Trade Issues, edited by K. Anderson and R. Blackhurst, Ann Arbor: University of Michigan Press and London: Harvester Wheatsheaf.

Anderson, K. 1992b. "Effects on the Environment and Welfare of Liberalizing World Trade: The Cases of Coal and Food", Ch.8 in The Greening of World Trade Issues, edited by $\mathrm{K}$. Anderson and R. Blackhurst, Ann Arbor: University of Michigan Press and London: Harvester Wheatsheaf.

Anderson, K. 1992c. "Agricultural Trade Liberalisation and the Environment: A Global Perspective", The World Economy 15(1): 153-71, January.

Anderson, K. 1993. "Economic Growth, Environmental Issues and Trade", Ch. 11 in Pacific Dynamism and the International Economic System, edited by C.F. Bergsten and M. Noland, Washington, D.C.: Institute for International Economics. Anderson, K. 1995. 'The Entwining of Trade Policy With Environmental and Labor Standards', Ch. 14 in The Uruguay Round and the Developing Countries, Discussion Paper 307, edited by W. Martin and L.A. Winters, Washington, D.C.: The World Bank.

Anderson, K. and J. Drake-Brockman. 1995. 'Trade and Environment Policy Issues: Implications for the Asia-Pacific Region', Canberra: AUSPECC (Australian Pacific Economic Cooperation Committee), February. 
Baldwin, R. 1995. 'Does Sustainability Require Growth?', in The Economics of Sustainable Development, edited by I. Goldin and L.A. Winters, Cambridge: Cambridge University Press.

Barbier, E.B., J.C. Burgess, T.M. Swanson and D.W. Pearce. 1990. Elephants, Economics and Ivory, London: Earthscan.

Baumol, W. 1971. Environmental Protection, International Spillovers and Trade, Stockholm: Almqvist and Wiksell.

Beckerman, W. 1992. "Economic Growth and the Environment: Whose Growth? Whose Environment?", World Development 20(4): 481-96.

Benedick, R.E. 1991. Ozone Diplomacy, Cambridge: Harvard University Press.

Beltratti, A. 1995. 'Can a Growth Model With Defensive Expenditures Generate an Environmental Kuznets Curve?' paper for a workshop on Designing Economic Policy for Management of Natural Resources and the Environment, 12-13 May, Venice.

Bhagwati, J.N. 1996. 'The Demand to Reduce Domestic Diversity Among Trading Nations', Ch. 1 in Fair Trade and Harmonization: Prerequisites for Free Trade? Vol. 1, edited by J.N. Bhagwati and R. E. Hudec, Cambridge: MIT Press.

Bhagwati, J.N. 1995. 'Trade and Wages: Choosing Among Alternative Explanations', Federal Reserve Bank of New York Economic Policy Review, January.

Bhagwati, J.N. and V.H. Dehejia. 1994. 'Freer Trade and Wages of the Unskilled: Is Marx Striking Again?', Ch. 2 in Trade and Wages: Levelling Wages Down? edited by J.N. Bhagwati and M.H. Kosters, Washington, D.C.: American Enterprise Institute Press. 
Bhagwati, J.N. and T.N. Srinivasan. 1996. 'Trade and the Environment: Does Environmental Diversity Detract from the Case for Free Trade?' Ch. 4 in Fair Trade and Harmonization: Prerequisites for Free Trade? Vol. 1, edited by J.N. Bhagwati and R. E. Hudec, Cambridge: MIT Press.

Brown, D.K., A.V. Deardorff and R.M. Stern. 1996. 'International Labor Standards and Trade: A Theoretical Analysis', CH, 5 in Fair Trade and Harmonization: Prerequisites for Free Trade? Vol. 1, edited by J.N. Bhagwati and R. E. Hudec, Cambridge: MIT Press.

Burtless, G. 1995. 'International Trade and the Rise of Earnings Inequality', Journal of Economic Literature 33(2): 800-16, June.

Casella, A. 1996. 'Free Trade and Evolving Standards', Ch. 3 in Fair Trade and Harmonization: Prerequisites for Free Trade? Vol. 1, edited by J.N. Bhagwati and R. E. Hudec, Cambridge: MIT Press.

Charnovitz, S. 1987. The Influence of International Labour Standards on the World Trading Regime: A Historical Review', International Labour Review 126(5): 56584 , September-October.

Charnovitz, S. 1991. 'Exploring the Environmental Exceptions in GATT Article XX', Journal of World Trade 25(5), October.

Chichilnisky, G. 1994. 'North-South Trade and the Global Environment', American Economic Review 84(4): 851-74, September.

Copland, B. R. and M. S. Taylor. 1995. 'Trade and Transboundary Pollution,' American Economic Review 85(4): 716-37, September.

Corden, W.M. and R. Findlay. 1975. 'Urban Unemployment, Intersectoral Capital Mobility and Development Policy', Economica 42: 59-78, February. 
Deacon, R. and P. Shapiro. 1975. "Private Preference for Collective Goods Revealed Through Voting on Referenda", American Economic Review 65: 943-55.

Ehrenberg, R. 1994. Labour Markets and Integrating National Economies, Washington, D.C.: Brookings Institution.

Enders, A. and A. Porges. 1992. "Successful Conventions and Conventional Success: Saving the Ozone Layer", Ch.7 in The Greening of World Trade Issues, edited by K. Anderson and R. Blackhurst, Ann Arbor: University of Michigan Press and London: Harvester Wheatsheaf.

Esty, D.C. 1994. Greening the GATT: Trade, Environment, and the Future, Washington, D.C.: Institute for International Economics.

Farber, D.A. and R.E. Hudec. 1996. 'GATT Legal Restraints on Domestic Environmental Regulations', Ch. 3 in Fair Trade and Harmonization: Prerequisites for Free Trade? Vol. 2, edited by J.N. Bhagwati and R. E. Hudec, Cambridge: MIT Press.

Falvey, R. 1995. 'International Trade and Factor Price Convergence', Working Paper No. 290, Australian National University, Canberra, August.

Finger, J.M. 1995. 'Legalized Backsliding: Safeguard Provision in the GATT', Ch. 8 in The Uruguay Round and the Developing Countries, Discussion Paper 307, edited by W. Martin and L.A. Winters, Washington, D.C.: The World Bank.

Francois, J.F., B. McDonald and H. Nordstrom. 1995. 'Assessing the Uruguay Round', Ch. 6 in The Uruguay Round and the Developing Countries, Discussion Paper 307, edited by W. Martin and L.A. Winters, Washington, D.C.: The World Bank.

GATT. 1971. Industrial Pollution Control and International Trade, GATT Studies in International Trade No.1, Geneva: GATT Secretariat.

GATT. 1991. Trade Policy Review: Indonesia, Geneva: GATT Secretariat, August. 
GATT. 1992. International Trade 1990-91, Volume I, Geneva: General Agreement on Tariffs and Trade.

GATT. 1994. International Trade Statistics 1994, Geneva: GATT Secretariat.

Grossman, G.M. 1995. 'Pollution and Growth: What Do We Know?', in The Economics of Sustainable Development, edited by I. Goldin and L.A. Winters, Cambridge: Cambridge University Press.

Grossman, G.M. and A.B. Krueger. 1993. "Environmental Impacts of a North American Free Trade Agreement", pp. 13-56 in The Mexico-U.S. Free Trade Agreement, edited by P.M. Garber, Cambridge: MIT Press.

Grossman, G.M. and A.B. Krueger. 1995. 'Economic Growth and the Environment', Quarterly Journal of Economics 110(2): 353-78, May.

Hanson, G. 1983. Social Clauses and International Trade: An Economic Analysis of Labour Standards in Trade Policy, New York: St Martins Press.

Hillman, A.L. and H.N. Ursprung. 1992. "The Influence of Environmental Concerns on the Political Determination of Trade Policy", Ch.10 in The Greening of World Trade Issues, edited by K. Anderson and R. Blackhurst, Ann Arbor: University of Michigan Press and London: Harvester Wheatsheaf.

Hoekman, B. and M. Leidy. 1992. "Environmental Policy Formation in a Trading Economy: a Public Choice Perspective", Ch.11 in The Greening of World Trade Issues, edited by K. Anderson and R. Blackhurst, Ann Arbor: University of Michigan Press and London: Harvester Wheatsheaf.

Hudec, R.E. 1996. 'GATT Legal Restraints on the Use of Trade Measures Against Foreign Environmental Practices', Ch. 3 in Fair Trade and Harmonization: 
Prerequisites for Free Trade? Vol. 2, edited by J.N. Bhagwati and R. E. Hudec, Cambridge: MIT Press.

International Labour Organisation. 1956. Social Aspects of European Economic Cooperation, Report by a Group of Experts (the Ohlin Report), Geneva: ILO.

Jaffe, A.B., S.R. Peterson, P.R. Portney and R.N Stavins. 1995. 'Environmental Regulation and the Competitiveness of U.S. Manufacturing: What Does the Evidence Tell Us?', Journal of Economic Literature 33(1): 132-63, March.

Jones, L.A. and R.E. Manuelli. 1995. 'A Positive Model of Growth and Pollution Controls', NBER Working Paper No. 5205, Cambridge Mass., August.

Krueger, A. 1977. Growth, Distortions and Patterns of Trade Among Many Countries, Princeton, N.J.: International Finance Section.

Krugman, P. and R.Z. Lawrence. 1994. 'Trade, Jobs, and Wages', Scientific American 270(4): 44-49, April.

Lawrence, R.Z. 1994. 'Trade, Multinationals, and Labour', in International Integration of the Australian Economy, edited by P. Lowe and J. Dwyer, Sydney: Reserve Bank of Australia.

Lawrence, R.Z. 1995. Regionalism, Multilateralism, and Deeper Integration, Washington, D.C.: Brookings Institution.

Leamer, E.E. 1987. "Paths of Development in the Three Factor, n-Good General Equilibrium Model", Journal of Political Economy 95(5):961-99, October.

Leonard, N.J. 1988. Pollution and the Struggle for World Product: Multinational Corporations, Environment and International Comparative Advantage, Cambridge: Cambridge University Press. 
Levinson, A. 1996. 'Environmental Regulation and Industry Location: International and Domestic Evidence', Ch. 11 in Fair Trade and Harmonization: Prerequisites for Free Trade? Vol. 1, edited by J.N. Bhagwati and R. E. Hudec, Cambridge: MIT Press.

Low, P. 1992. "Trade Measures and Environmental Quality: The Implications for Mexico's Exports", Ch.7 in International Trade and the Environment, Discussion Paper 159, edited by P. Low, Washington, D.C.: The World Bank.

Meadows, D.H. et al. 1972. The Limits to Growth, New York: Universe Books.

National Research Council. 1995. Standards, Conformity Assessment, and Trade into the 21st Century, Washington, D.C.: National Academy Press.

Radetzki, M. 1992. 'Economic Growth and Environment', Ch. 8 in International Trade and the Environment, Discussion Paper 159, edited by P. Low, Washington, D.C.: The World Bank.

Rodrik, D. 1994. 'Developing Countries After the Uruguay Round', paper prepared for the Group of 24, mimeo, Columbia University, August. (CEPR Discussion Paper No. 1084, December 1994.)

Rybczynski, T.M. 1959. 'Factor Endowment and Relative Commodity Prices', Economica 22(84): 336-41, November.

Sapir, A. 1996. 'Trade Liberalization and the Harmonization of Social Policies: Lessons From European Integration', Ch. 15 in Fair Trade and Harmonization: Prerequisites for Free Trade? Vol. 1, edited by J.N. Bhagwati and R. E. Hudec, Cambridge: MIT Press.

Siebert, H. 1974. "Environmental Protection and International Specialization", Welwirtschaftliches Archiv 110: 494-508. 
Siebert, H., J. Eichberger, R. Gronych and R. Pethig. 1980. Trade and Environment: A Theoretical Enquiry, Amsterdam: Elsevier.

Snape, R.H. 1992. "The Environment, International Trade and Competitiveness", Ch.4 in The Greening of World Trade Issues, edited by K. Anderson and R. Blackhurst, Ann Arbor: University of Michigan Press and London: Harvester Wheatsheaf.

Steenblik, R.P. and P. Coroyannakis. 1995. 'Reform of Coal Policies in Western and Central Europe: Implications for the Environment', Energy Policy 23(6): 537-54, June.

Steil, B. 1994. “'Social Correctness' is the New Protectionism”, Foreign Affairs 73(1): 14-20, January/February.

Tobey, J.A. 1990. "The Effects of Domestic Environmental Policies on Patterns of World Trade: An Empirical Test", Kyklos 43(2): 191-209.

Tyers, R. and Y. Yang 1995. 'Trade with Asia and Skill Upgrading: Effects on Factor Markets in the Older Industrial Countries', mimeo, Australian National University, Canberra, October.

Ulph, A. 1994. "Environmental Policy and International Trade -- A Survey of Recent Economic Analysis", paper presented to the Workshop on Designing Economic Policy for the Management of Natural Resources and the Environment, Crete, 7-9 September.

Van Grasstek, C. 1992. "The Political Economy of Trade and the Environment in the United States", Ch.13 in International Trade and the Environment, edited by P. Low, Discussion Paper 159, Washington, D.C.: The World Bank.

Walter, I. 1975. The International Economics of Pollution, London: Macmillan. 
Walter, I., ed. 1976. Studies in International Environmental Economics, New York: Wiley.

Wilson, J.D. 1996. 'Capital Mobility and Environmental Standards: Is There a Theoretical Basis for a Race to the Bottom?' Ch. 10 in Fair Trade and Harmonization: Prerequisites for Free Trade? Vol. 1 edited by J.N. Bhagwati and R. E. Hudec, Cambridge: MIT Press.

Wood, A. 1994. North-South Trade, Employment and Inequality: Changing Fortunes in a Skill-Driven World, Oxford: Clarendon Press.

World Bank. 1993. World Development Report 1993, New York: Oxford University Press.

World Bank. 1994. World Development Report 1994, New York: Oxford University Press.

World Bank. 1995. World Development Report 1995, New York: Oxford University Press.

Zarsky, L. and J. Drake-Brockman. 1994. 'Trade, Environment, and APEC', CAPA Report No. 18, San Francisco: Asia Foundation, December. 